\title{
The Influence of ACE Insertion/Deletion Gene Polymorphism on the Risk of IgA Nephropathy: A Debatable Topic
}

\author{
Fen-Fen Chu $\mathbb{D},{ }^{1}$ Shi-Kun Yang $\mathbb{D},^{2}$ and Wen-Li Zeng $\mathbb{D}^{1}$ \\ ${ }^{1}$ Department of Nephrology, The First Affiliated Hospital of the University of South China, Hengyang 421001, \\ Hunan Province, China \\ ${ }^{2}$ Department of Nephrology, The Third Xiangya Hospital of Central South University, Changsha 410013, Hunan Province, China \\ Correspondence should be addressed to Wen-Li Zeng; docwenlizeng@163.com
}

Received 12 May 2021; Revised 11 October 2021; Accepted 19 October 2021; Published 18 November 2021

Academic Editor: Hafiz Ishfaq Ahmad

Copyright ( 92021 Fen-Fen Chu et al. This is an open access article distributed under the Creative Commons Attribution License, which permits unrestricted use, distribution, and reproduction in any medium, provided the original work is properly cited.

Background. The connection between angiotensin-converting enzyme insertion/deletion (ACE I/D) gene polymorphisms and IgA nephropathy (IgAN) was conflicting. This pooled analysis was performed to explore this issue. Methods. All eligible investigations were identified from various electronic databases, and the pooled analysis was evaluated using Stata software. Results. 27 studies with 2538 IgAN cases and 3592 controls were included. In overall subjects, ACE $D$ allele, DD, and II genotype were associated with IgAN susceptibility (D vs. I: OR = 1.21, 95\% CI: 1.10-1.32, $P<0.001$; DD vs. ID + II: OR = 1.38, 95\% CI: $1.20-1.60, P<0.001 ;$ and II vs. $\mathrm{DD}+\mathrm{ID}: \mathrm{OR}=0.83,95 \% \mathrm{CI}: 0.73-0.95, P=0.007)$. In Asian and Chinese patients, ACE I/D gene polymorphism was also correlated with IgAN vulnerability. Moreover, ACE $D$ allele, DD, and II genotype were correlated with the progression of IgAN (D vs. I: $\mathrm{OR}=1.37,95 \% \mathrm{CI}: 1.09-1.73, P=0.008$; DD vs. ID + II: $\mathrm{OR}=1.57,95 \% \mathrm{CI}: 1.06-2.31, P=0.024$; and II vs. DD + ID: $\mathrm{OR}=0.69,95 \% \mathrm{CI}: 0.49-0.99, P=0.045)$. Conversely, in Caucasian subjects, there was no link between ACE I/D gene polymorphism and the risk of IgAN. Conclusion. ACE I/D gene polymorphism was correlated with the vulnerability and progression of IgAN in Asian and Chinese patients, and ACE D allele and DD homozygote genotype could be adverse factors for IgAN, while the II homozygote genotype could be an advantage factor. But, no significant association was found between ACE I/D gene polymorphism and IgAN in Caucasians.

\section{Introduction}

IgA nephropathy (IgAN) is a common type of glomerulonephritis globally; in the Pacific Asian region, the prevalence rate of IgAN is even more high [1]. It is a serious public health problem with very high mortality and morbidity, and recent studies have showed that approximately $20 \%$ IgAN patients would progress to endstage renal disease (ESRD) if lacking effective treatment [2]. The presence of excessive immune complexes including IgA in the glomerulus was a key mechanism of IgAN. The current therapy was mainly on corticosteroids and immunosuppressors [3]. However, these measures were not fully effective. Recent research found that susceptibility to IgAN was influenced by a confluence of some genetic factors, and more importantly, some single-gene polymorphisms were associated with the susceptibility of IgAN [4].

Angiotensin-converting enzyme (ACE) was a key enzyme that converted angiotensin I to angiotensin II. The ACE gene consisted of 26 exons and located on chromosome 17q23 [5]. Single-nucleotide polymorphisms (SNPs) frequently occurred in the ACE gene; in the 16th intron of the ACE gene, a $287 \mathrm{bp}$ fragment recognized as insertion/deletion $(I / D)$ polymorphism has been found, and based on this I/D polymorphic marker locus, three genotypes could be defined: DD, II homozygotes, and ID heterozygote [6]. It has been found that serum ACE activity could be affected by ACE I/D gene polymorphisms, and these subjects with the $D$ allele always have higher level of ACE activity [7]. Some research studies have demonstrated that ACE I/D polymorphism would affect the vulnerability of IgAN [8-10]. 
TABLE 1: Characteristics of studies included in the meta-analysis.

\begin{tabular}{|c|c|c|c|c|c|c|c|c|c|c|c|c|c|}
\hline \multirow{2}{*}{ Trials } & \multirow{2}{*}{ Design } & \multirow{2}{*}{$\begin{array}{l}\text { Country; } \\
\text { ethnicity }\end{array}$} & \multirow{2}{*}{ Year } & \multirow{2}{*}{$\begin{array}{l}\text { Sex }(M / \\
F)\end{array}$} & \multirow{2}{*}{ Case } & \multirow{2}{*}{ Control } & \multicolumn{3}{|c|}{ Case } & \multicolumn{3}{|c|}{ Control } & \multirow{2}{*}{$\begin{array}{l}\text { HWE } \\
\text { (p) }\end{array}$} \\
\hline & & & & & & & $\mathrm{DD}$ & ID & II & DD & ID & II & \\
\hline Harden, 1995 & $\begin{array}{l}\text { Case } \\
\text { control }\end{array}$ & UK; European & NR & NR & $' 100$ & 98 & 40 & 41 & 19 & 39 & 42 & 17 & 0.3351 \\
\hline Huang, 2010 & $\begin{array}{l}\text { Case } \\
\text { control }\end{array}$ & China; Asian & NR & NR & 130 & 120 & 19 & 67 & 44 & 10 & 52 & 58 & 0.7280 \\
\hline Hunley, 1996 & $\begin{array}{l}\text { Case } \\
\text { control }\end{array}$ & USA; American & $6-83$ & $43 / 21$ & $40^{\#}$ & $24^{*}$ & 8 & 24 & 8 & 1 & 14 & 9 & 0.1258 \\
\hline Lau, 2002 & $\begin{array}{l}\text { Case } \\
\text { control }\end{array}$ & Singapore; Asian & NR & $45 / 55$ & 100 & 90 & 8 & 43 & 49 & 8 & 40 & 42 & 0.7265 \\
\hline Lau, 2004 & $\begin{array}{l}\text { Case } \\
\text { control }\end{array}$ & China; Asian & $\begin{array}{c}P: 43 \pm 10 ; C: \\
48 \pm 14\end{array}$ & $\begin{array}{l}\text { P: } 56 / 62 \text {; } \\
\text { C: } 42 / 52\end{array}$ & 118 & 94 & 17 & 48 & 53 & 4 & 43 & 47 & 0.1280 \\
\hline Frimat, 2000 & $\begin{array}{l}\text { Case } \\
\text { control }\end{array}$ & $\begin{array}{l}\text { France; } \\
\text { European }\end{array}$ & NR & NR & 274 & 960 & 89 & 132 & 53 & 288 & 470 & 202 & 0.6891 \\
\hline $\begin{array}{l}\text { Maruyama, } \\
2001\end{array}$ & $\begin{array}{l}\text { Case } \\
\text { control }\end{array}$ & Japan; Asian & $\begin{array}{c}\text { P: } 10.6 \pm 2.9 ; C: \\
\text { NR }\end{array}$ & $\begin{array}{c}\text { P: 56/39; } \\
\text { C: NR }\end{array}$ & 95 & 99 & 15 & 42 & 38 & 10 & 33 & 56 & 0.1362 \\
\hline Pawlik, 2014 & $\begin{array}{c}\text { Case } \\
\text { control }\end{array}$ & $\begin{array}{l}\text { Poznan; } \\
\text { European }\end{array}$ & $\begin{array}{l}\text { P: NR; C: } \\
38.1 \pm 12.8\end{array}$ & $\begin{array}{l}\text { P : NR; } \\
\text { C: } 105 / \\
82\end{array}$ & 31 & 187 & 10 & 17 & 4 & 47 & 100 & 40 & 0.3315 \\
\hline Pei, 1997 & $\begin{array}{c}\text { Case } \\
\text { control }\end{array}$ & $\begin{array}{l}\text { Canada; } \\
\text { American }\end{array}$ & NR & NR & 168 & 100 & 55 & 81 & 32 & 30 & 49 & 21 & 0.9045 \\
\hline $\begin{array}{l}\text { Rodríguez- } \\
\text { Pérez, } 2009\end{array}$ & $\begin{array}{l}\text { Case } \\
\text { control }\end{array}$ & Spain; Europen & $\begin{array}{c}P: 33-46 ; C: \\
29-46\end{array}$ & $\begin{array}{l}\text { P: } 10 / 3 \\
\text { C: } 42 / 9\end{array}$ & 13 & 51 & 7 & 4 & 2 & 21 & 24 & 6 & 0.8287 \\
\hline Santos, 2002 & $\begin{array}{l}\text { Case } \\
\text { control }\end{array}$ & USA; American & NR & NR & 79 & 53 & 17 & 45 & 17 & 13 & 32 & 8 & 0.1119 \\
\hline Schmidt, 1995 & $\begin{array}{c}\text { Case } \\
\text { control }\end{array}$ & $\begin{array}{c}\text { Germany, } \\
\text { Australia, Italy; } \\
\text { mixed }\end{array}$ & NR & $\begin{array}{c}\text { P: } 153 / \\
51 ; C: \\
\text { NR }\end{array}$ & 204 & 234 & 79 & 81 & 44 & 77 & 117 & 40 & 0.6949 \\
\hline Stratta, 1999 & $\begin{array}{l}\text { Case } \\
\text { control }\end{array}$ & Italy; European & NR & $\begin{array}{l}\text { P: } 67 / 14 \text {; } \\
\text { C: } 25 / 25\end{array}$ & 81 & 50 & $\begin{array}{c}35 \\
20^{\#}\end{array}$ & $\begin{array}{l}30 \\
16^{\#}\end{array}$ & $\begin{array}{l}16 \\
5^{\#}\end{array}$ & $\begin{array}{l}21 \\
9^{*}\end{array}$ & $\begin{array}{c}20 \\
13^{*}\end{array}$ & $98^{*}$ & $\begin{array}{l}0.2853 \\
0.4684\end{array}$ \\
\hline Suzuki, 2000 & $\begin{array}{c}\text { Case } \\
\text { control }\end{array}$ & Japan; Asian & $\begin{array}{c}\mathrm{P:} 39.2 \pm 12.3 ; \mathrm{C} \\
\quad 34.9 \pm 13.5\end{array}$ & $\begin{array}{c}\text { P: } 49 / 34 ; \\
\text { C: } 117 / \\
133\end{array}$ & $83^{\#}$ & $250^{*}$ & $13^{\#}$ & $31^{\#}$ & $39^{\#}$ & $35^{*}$ & $107^{*}$ & $108^{*}$ & 0.3100 \\
\hline Syrjänen, 2000 & $\begin{array}{l}\text { Case } \\
\text { control }\end{array}$ & $\begin{array}{l}\text { Finland; } \\
\text { European }\end{array}$ & NR & NR & $26^{\#}$ & $142^{*}$ & $9^{\#}$ & $16^{\#}$ & $1^{\#}$ & $45^{*}$ & $67^{*}$ & $30^{*}$ & 0.5861 \\
\hline Tanaka, 1998 & $\begin{array}{l}\text { Case } \\
\text { control }\end{array}$ & Japan; Asian & NR & NR & 97 & 71 & 15 & 48 & 34 & 9 & 35 & 27 & 0.6513 \\
\hline Woo, 2004 & $\begin{array}{c}\text { Case } \\
\text { control }\end{array}$ & Singapore; Asian & $\begin{array}{c}P: 43 \pm 10 ; C: \\
48 \pm 14\end{array}$ & $\begin{array}{l}\text { P: } 56 / 62 \text {; } \\
\text { C: } 42 / 52\end{array}$ & 118 & 94 & 17 & 48 & 53 & 4 & 43 & 47 & 0.1280 \\
\hline Yoshida, 1995 & $\begin{array}{l}\text { Case } \\
\text { control }\end{array}$ & Japan; Asian & $\begin{array}{c}P: 38.2 \pm 2.1 ; \mathrm{C}: \\
35.8 \pm 1.8\end{array}$ & $\begin{array}{l}\text { P: } 34 / 19 \text {; } \\
\text { C: } 24 / 22\end{array}$ & 53 & 46 & $\begin{array}{l}16 \\
12^{\#}\end{array}$ & $\begin{array}{l}17 \\
8^{\#}\end{array}$ & $\begin{array}{l}20 \\
8^{\#}\end{array}$ & $34^{*}$ & $249^{*}$ & $\begin{array}{c}19 \\
12^{*}\end{array}$ & $\begin{array}{l}0.2045 \\
0.3225\end{array}$ \\
\hline Hu, 1997 & $\begin{array}{l}\text { Case } \\
\text { control }\end{array}$ & China; Asian & $36.5 \pm 7.5$ & $55 / 27$ & $51^{\#}$ & $31^{*}$ & $14^{\#}$ & $26^{\#}$ & $11^{\#}$ & $8^{*}$ & $13^{*}$ & $10^{*}$ & 0.3797 \\
\hline Li, 2007 & $\begin{array}{l}\text { Case } \\
\text { control }\end{array}$ & China; Asian & $\begin{array}{c}\text { P: } 34.8 \pm 15.8 ; \mathrm{C}: \\
33.1 \pm 13.9\end{array}$ & $\begin{array}{l}\text { P: } 30 / 34 \text {; } \\
\text { C: } 26 / 54\end{array}$ & 64 & 80 & 8 & 32 & 24 & 6 & 42 & 32 & 0.1196 \\
\hline Liao, 2003 & $\begin{array}{l}\text { Case } \\
\text { control }\end{array}$ & China; Asian & $\begin{array}{c}P: 17-68 ; C: \\
19-65\end{array}$ & $\begin{array}{l}\text { P: } 60 / 35 \text {; } \\
\text { C: } 58 / 47\end{array}$ & 95 & 105 & 27 & 35 & 33 & 21 & 42 & 42 & 0.0877 \\
\hline Liu, 2005 & $\begin{array}{c}\text { Case } \\
\text { control }\end{array}$ & China; Asian & $\begin{array}{c}\text { P: } 29.7 \pm 10.7 ; C: \\
\text { NR }\end{array}$ & $\begin{array}{c}\text { P: } 98 / 48 \\
\text { C: NR }\end{array}$ & 146 & 146 & 18 & 78 & 50 & 9 & 86 & 51 & 0.0006 \\
\hline Liu, 1997 & $\begin{array}{c}\text { Case } \\
\text { control }\end{array}$ & China; Asian & $\begin{array}{c}\text { P: 9-42; C: } \\
\quad 18-55\end{array}$ & $\begin{array}{c}\text { P: 106/ } \\
\text { 71; C: } \\
\text { 54/96 }\end{array}$ & 177 & 150 & 31 & 81 & 65 & 9 & 59 & 82 & 0.7059 \\
\hline Song, 2017 & $\begin{array}{l}\text { Case } \\
\text { control }\end{array}$ & China; Asian & $\begin{array}{c}\mathrm{P}: 42.9 \pm 12.3 ; \mathrm{C}: \\
\quad 43.7 \pm 13.5\end{array}$ & $\begin{array}{l}\text { P: } 23 / 22 \text {; } \\
\text { C: } 27 / 18\end{array}$ & 45 & 45 & 9 & 18 & 18 & 15 & 18 & 12 & 0.1876 \\
\hline $\mathrm{Xu}, 2001$ & $\begin{array}{l}\text { Case } \\
\text { control }\end{array}$ & China; Asian & $\begin{array}{c}P: 11-56 ; C: \\
20-68\end{array}$ & $\begin{array}{l}\text { P: } 63 / 47 \text {; } \\
\text { C: } 73 / 43\end{array}$ & 110 & 116 & 25 & 39 & 46 & 24 & 40 & 52 & 0.0039 \\
\hline You, 2013 & $\begin{array}{l}\text { Case } \\
\text { control }\end{array}$ & China; Asian & $\begin{array}{c}\mathrm{P}: 33.6 \pm 12.5 ; \mathrm{C}: \\
31.5 \pm 10.8\end{array}$ & $\begin{array}{l}\text { P: } 36 / 32 \text {; } \\
\text { C: } 34 / 36\end{array}$ & 68 & 70 & 26 & 30 & 12 & 13 & 39 & 18 & 0.3154 \\
\hline Zheng, 1999 & $\begin{array}{l}\text { Case } \\
\text { control }\end{array}$ & China; Asian & P: 29.8; C: 33.1 & $\begin{array}{l}\text { P: } 44 / 28 ; \\
\text { C: } 16 / 70\end{array}$ & 72 & 86 & 9 & 36 & 27 & 8 & 44 & 34 & 0.2419 \\
\hline
\end{tabular}

Note. P: IgA nephropathy subjects; C: control subjects; HB, hospital based; PB: population based; NR: not reported; PCR, polymerase chain reaction; RFLP, restriction fragment length polymorphism. "Progression of IgAN; *nonprogression of IgAN. 


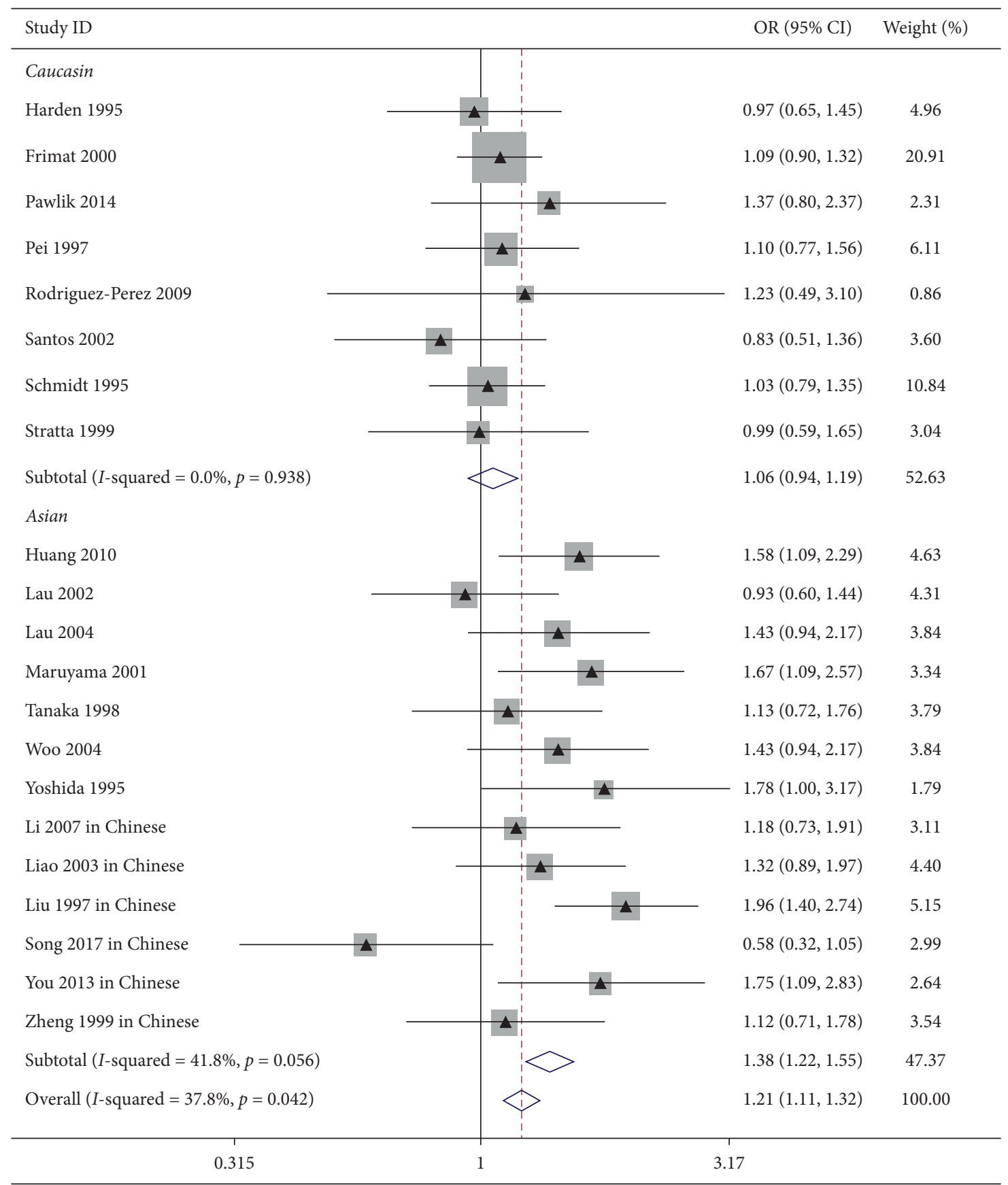

FIGURe 1: Forest plot of ACE I/D gene polymorphism linked with IgAN susceptibility (D allele vs. I allele). Pooled analysis indicated that the ACE gene locus D allele was a risk factor of IgAN in the overall and Asian subjects.

However, up to now, the role of ACE I/D polymorphism in the occurrence of IgAN is still inconsistent and controversial. So, in this study, we included much more highquality studies to further assess the influence of ACE I/D gene polymorphism on IgAN susceptibility.

\section{Methods}

2.1. Study Search and Inclusion Strategy. We searched relevant studies from various electronic databases (e.g., PubMed, Scopus, and CNKI database) for eligible trials (all till Oct 2021). Multiple search keywords were used: IgA nephropathy, renal disease, kidney, nephropathy, ACE, ACE I/D, angiotensin-converting enzyme, insertion/deletion, gene, and gene polymorphism. The inclusion criteria of this study included the following: (1) the study included two comparison groups (IgA patients vs. control subjects or progression IgA patients vs. nonprogression IgA patients). (2) The number of ACE I/D genotypes could to be calculated. (3) The genotype distributions in control group was in accordance with Hardy-Weinberg Equilibrium (HWE). 


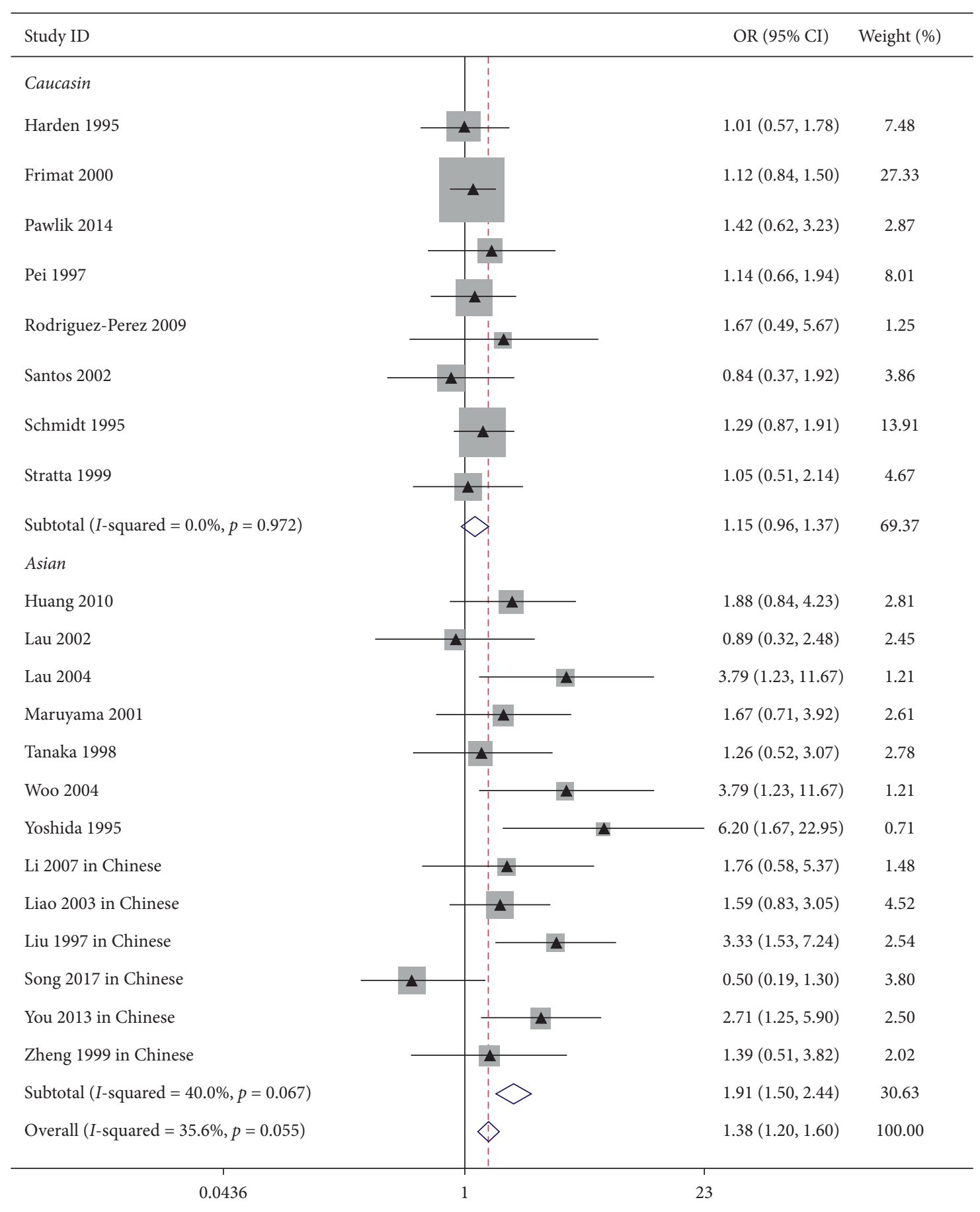

FIGURE 2: Forest plot about the link between ACE I/D gene polymorphism and IgAN risk (genotype DD vs. genotype ID + II). It showed that the ACE gene locus DD genotype was a risk factor of IgAN in the overall and Asian patients.

2.2. Data Analysis. In this study, we used the Stata software to perform this pooled analysis. An odds ratio (OR) was calculated to evaluate the influence of $\mathrm{ACE} I / D$ gene polymorphism on IgAN susceptibility, and four different genetic models were used: model 1 , allele $D$ vs. allele I; model 2 , genotype DD vs. genotype ID + II; model 3, genotype II vs. genotype $\mathrm{DD}+\mathrm{ID}$; and model 4 , genotype ID vs. genotype
DD + II. When a $P$ value was less than 0.05 , it was considered as statistically significant for the pooled OR. The heterogeneity among various included studies was evaluated using a $Q$ test. Additionally, Begg's test was completed to evaluate the publication bias; when the $P$ value of Begg' $s$ test was less than 0.05 , potential publication bias was most likely to exist [11]. 


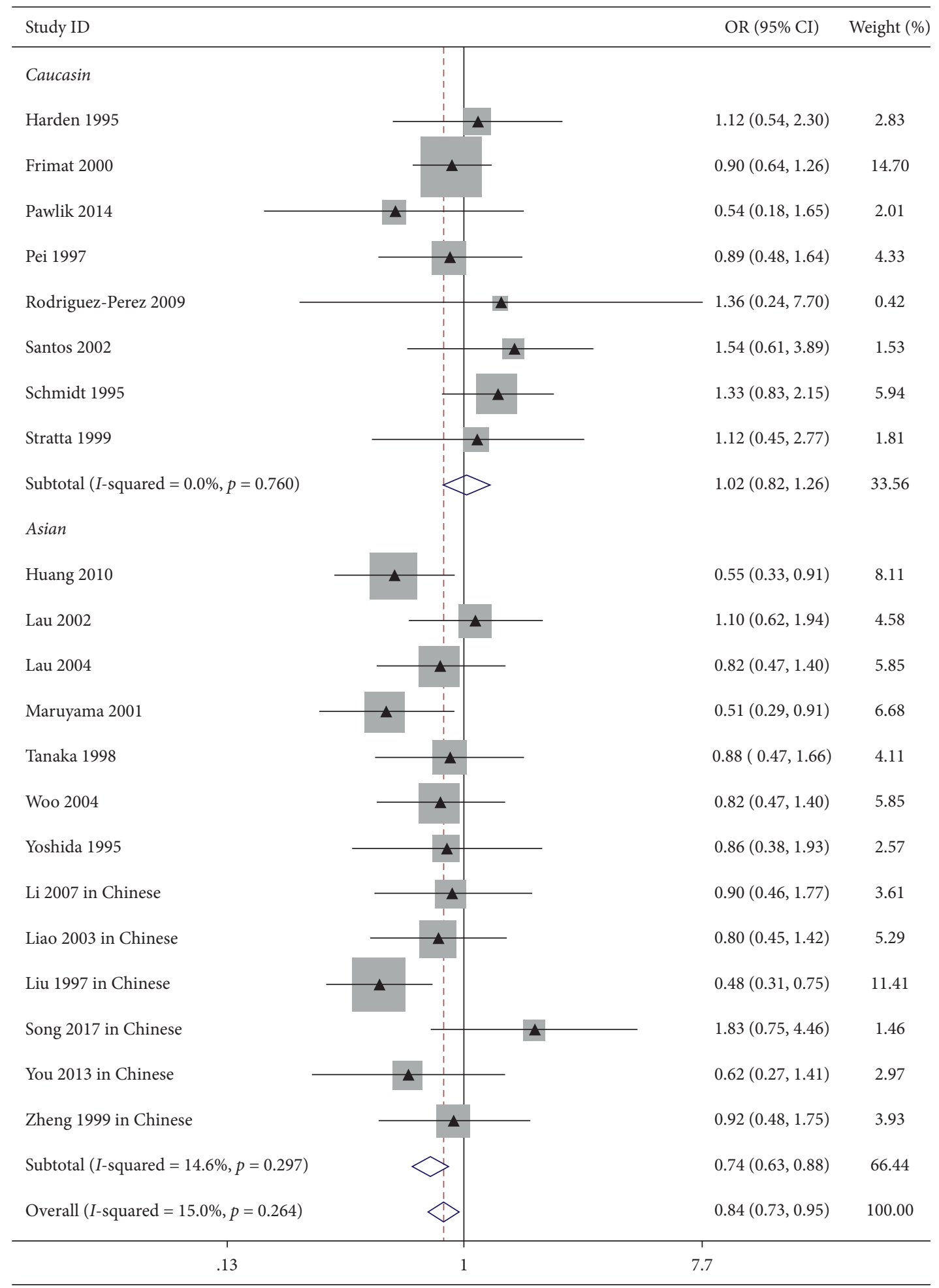

Figure 3: Forest plot about the link between ACE I/D gene polymorphism and IgAN risk (II genotype vs. DD + ID genotype). Evaluates of pooled OR for IgAN showed that the ACE gene locus II genotype was a protective factor of IgAN in the overall and Asian populations.

\section{Results}

3.1. Characteristics of the Included Studies. As shown in Table 1, 27 studies were finally included in our study [9,12-37], but 2 trials were excluded due to the fail to meet the HWE $[32,35]$. The main features of the included trials are described in Table 1. 6130 participants with 2538 cases and 3592 controls were included, and 9 of the studies were written in Chinese and 18 in English, from a total of 11 countries. The average age of participants ranged from 6 to 
TABLE 2: Meta-analysis of the link between ACE gene locus I/D polymorphisms and the susceptibility and progression of IgAN.

\begin{tabular}{|c|c|c|c|c|c|c|c|}
\hline Genetic contrasts & Group and subgroups & Study number & $Q$ test $p$ value & Model selected & OR $(95 \% \mathrm{CI})$ & $P$ value & Begg's test \\
\hline \multirow{6}{*}{ D versus I } & Overall & 21 & 0.042 & Fixed & $1.21(1.10-1.32)$ & $<0.001$ & 0.729 \\
\hline & Asian & 13 & 0.056 & Fixed & $1.38(1.22-1.55)$ & $<0.001$ & - \\
\hline & Caucasian & 8 & 0.938 & Fixed & $1.06(0.94-1.19)$ & 0.369 & - \\
\hline & Chinese & 8 & 0.035 & Fixed & $1.41(1.21-1.64)$ & $<0.001$ & - \\
\hline & Non-Chinese & 13 & 0.529 & Fixed & $1.12(1.01-1.24)$ & 0.031 & - \\
\hline & IgAN progression & 6 & 0.128 & Fixed & $1.37(1.09-1.73)$ & 0.008 & - \\
\hline \multirow{6}{*}{$\mathrm{DD}$ versus $\mathrm{ID}+\mathrm{II}$} & Overall & 21 & 0.055 & Fixed & $1.38(1.20-1.60)$ & $<0.001$ & 0.044 \\
\hline & Asian & 13 & 0.067 & Fixed & $1.91(1.50-2.44)$ & $<0.001$ & - \\
\hline & Caucasian & 8 & 0.972 & Fixed & $1.15(0.96-1.37)$ & 0.137 & - \\
\hline & Chinese & 8 & 0.089 & Fixed & $1.89(1.41-2.55)$ & $<0.001$ & - \\
\hline & Non-Chinese & 13 & 0.373 & Fixed & $1.25(1.06-1.47)$ & 0.009 & - \\
\hline & IgAN progression & 6 & 0.340 & Fixed & $1.57(1.06-2.31)$ & 0.024 & - \\
\hline \multirow{6}{*}{ II versus DD + ID } & Overall & 21 & 0.264 & Fixed & $0.83(0.73-0.95)$ & 0.007 & 0.294 \\
\hline & Asian & 13 & 0.297 & Fixed & $0.74(0.63-0.88)$ & $<0.001$ & - \\
\hline & Caucasian & 8 & 0.760 & Fixed & $1.02(0.82-1.26)$ & 0.865 & - \\
\hline & Chinese & 8 & 0.193 & Fixed & $0.71(0.58-0.88)$ & 0.001 & - \\
\hline & Non-Chinese & 13 & 0.640 & Fixed & $0.93(0.78-1.09)$ & 0.386 & - \\
\hline & IgAN progression & 6 & 0.117 & Fixed & $0.69(0.49-0.99)$ & 0.045 & - \\
\hline \multirow{6}{*}{ ID versus $\mathrm{DD}+\mathrm{II}$} & Overall & 21 & 0.615 & Fixed & $0.93(0.83-1.05)$ & 0.235 & 0.389 \\
\hline & Asian & 13 & 0.386 & Fixed & $0.98(0.84-1.16)$ & 0.858 & - \\
\hline & Caucasian & 8 & 0.796 & Fixed & $0.88(0.74-1.04)$ & 0.125 & - \\
\hline & Chinese & 8 & 0.568 & Fixed & $1.01(0.82-1.24)$ & 0.936 & - \\
\hline & Non-Chinese & 13 & 0.533 & Fixed & $0.89(0.78-1.03)$ & 0.131 & - \\
\hline & IgAN progression & 6 & 0.600 & Fixed & $1.00(0.72-1.39)$ & 0.997 & - \\
\hline
\end{tabular}

83 years. Additionally, the number of various genotypes were extracted and shown in Table 1.

\subsection{The Link between ACE I/D Gene Polymorphism and IgAN} Risk. The influence of ACE I/D gene polymorphism on IgAN risk was reported in 21 trials $[9,12,13,15,23,26,28,30,31,33,34,36,37]$. Our pooled analysis showed that ACE I/D gene polymorphism was associated with IgAN risk in the general populations (allele $D$ vs. allele I: $\mathrm{OR}=1.21,95 \% \mathrm{CI}: 1.10-1.32, P<0.001$, Figure 1; genotype $\mathrm{DD}$ vs. genotype ID + II: $\mathrm{OR}=1.38,95 \% \mathrm{CI}: 1.20-1.60$, $P<0.001$, Figure 2; and genotype II vs. genotype DD + ID: $\mathrm{OR}=0.83,95 \% \mathrm{CI}: 0.73-0.95, P=0.007$, Figure 3 and Table 2).

In the Asian patients, we also found a clear correlation between allele D/genotype DD and IgAN susceptibility (allele $D$ vs. allele I: $\mathrm{OR}=1.38,95 \% \mathrm{CI}$ : $1.22-1.55$, $P<0.001$, Figure 1; genotype DD vs. genotype ID + II: $\mathrm{OR}=1.91,95 \% \mathrm{CI}: 1.50-2.44, P<0.001$, Figure 2). Conversely, our analysis indicated that the ACE II genotype was a protecting factor against IgAN (genotype II vs. genotype $\mathrm{DD}+\mathrm{ID}: \quad \mathrm{OR}=0.74, \quad 95 \%$ CI: $0.63-0.88$, $P<0.001$, Figure 3 and Table 2).

In Caucasian subjects, the pooled analysis including 8 trials showed that there was no obvious link between ACE I/ $D$ gene polymorphism and IgAN risk (allele $D$ vs. allele I: $\mathrm{OR}=1.06,95 \% \mathrm{CI}: 0.94-1.19, P=0.369$, Figure 1 ; genotype $\mathrm{DD}$ vs. genotype ID + II: $\mathrm{OR}=1.15,95 \% \mathrm{CI}: 0.96-1.37$, $P=0.137$, Figure 2 ; genotype II vs. genotype $\mathrm{DD}+\mathrm{ID}$ : $\mathrm{OR}=1.02,95 \% \mathrm{CI}: 0.82-1.26, P=0.865$, Figure 3 ; and genotype ID vs. genotype $\mathrm{DD}+\mathrm{II}: \mathrm{OR}=0.88,95 \% \mathrm{CI}$ : $0.74-1.04, P=0.125$, Figure 4 , Table 2).

In this study, 8 trials reported the influence of ACE I/D gene polymorphism on IgAN vulnerability in Chinese patients. In line with Asian subjects, the pooled analysis indicated that allele $D$ and genotype DD were risk factors for IgAN (allele $D$ vs. allele I: $\mathrm{OR}=1.41,95 \% \mathrm{CI}$ : $1.21-1.64$, $P<0.001$, Figure 1; genotype DD vs. genotype ID + II: $\mathrm{OR}=1.89$, 95\% CI: $1.41-2.55, P<0.001$, Figure 2). Conversely, the ACE II genotype was an advantage factor for IgAN patients (genotype II vs. genotype $\mathrm{DD}+\mathrm{ID}: \mathrm{OR}=0.71$, 95\% CI: $0.58-0.88, P=0.001$, Figure 3 and Table 2).

\subsection{The Link between ACE I/D Gene Polymorphism and IgAN} Progression. There were 6 studies evaluating the influence of ACE I/D gene polymorphism on the progression of IgAN $[14,23,25,28,29]$, and the pooled analysis found that ACE I/D gene polymorphism was associated with IgAN progression (allele $D$ vs. allele I: $\mathrm{OR}=1.37,95 \% \mathrm{CI}: 1.09-1.73, P=0.008$; genotype $\mathrm{DD}$ vs. genotype ID $+\mathrm{II}: \mathrm{OR}=1.57,95 \% \mathrm{CI}$ : 1.06-2.31, $P=0.024$; and genotype II vs. genotype DD + ID: $\mathrm{OR}=0.69,95 \%$ CI: $0.49-0.99, P=0.045$, Table 2 ).

3.4. Publication Bias. The publication bias has been assessed using Begg' $s$ test and Funnel plots. Potential publication bias was found in the analysis for the link of genotype DD with IgAN risk (DD vs. ID + II genotype: Begg' $s P=0.044)$. Additionally, the funnel plot was asymmetrical (Table 2 and Figure 5). 


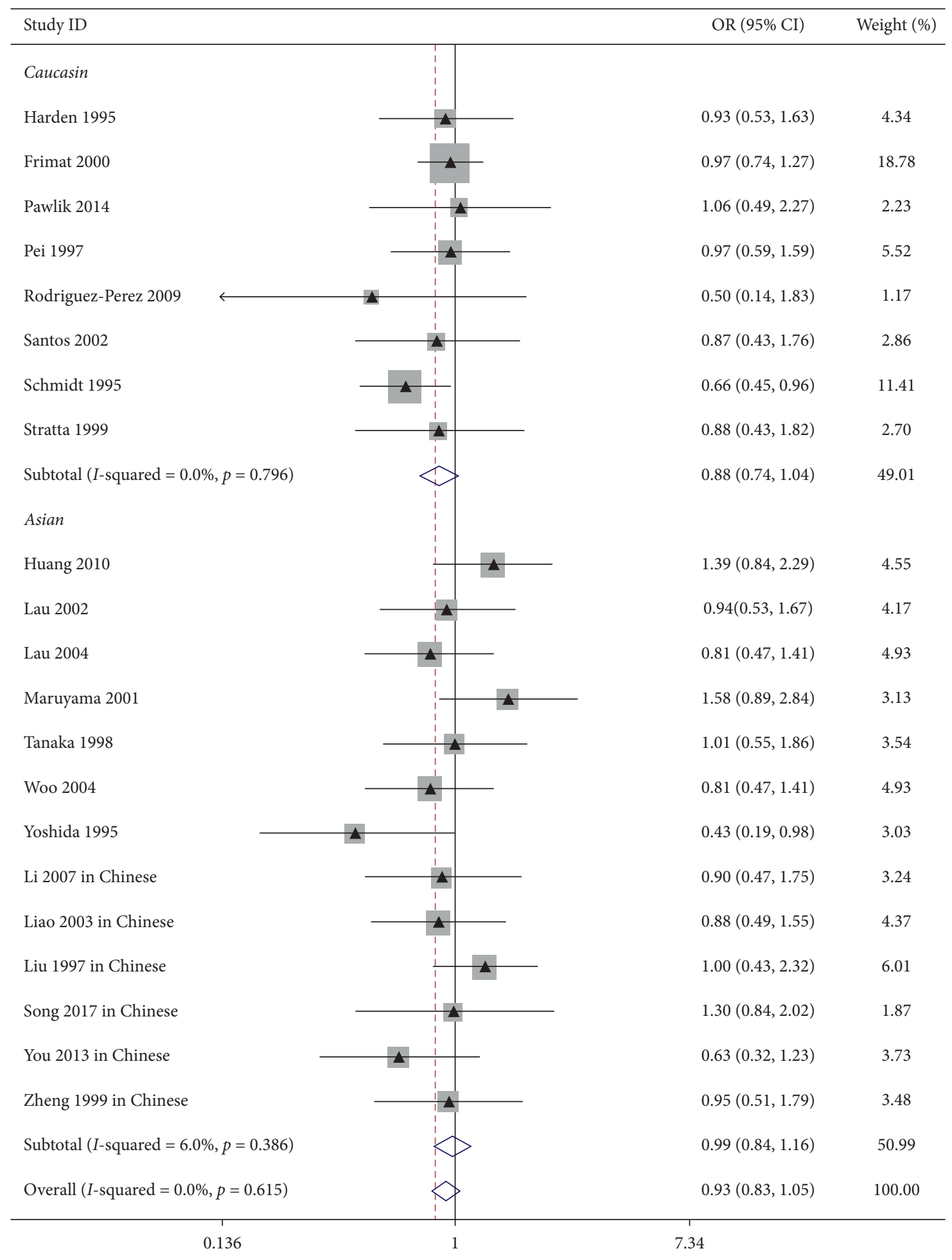

FIgURE 4: Forest plot about the link between ACE I/D gene polymorphism and IgAN susceptibility (genotype ID vs. genotype DD + II). Evaluates of pooled OR for IgAN showed that the ACE gene locus ID genotype was not associated with IgAN.

\section{Discussion}

Our study demonstrated that the ACE I/D polymorphism was associated with the susceptibility and progression of IgAN. Specifically, it showed that the ACE I/D gene $D$ allele and DD genotype were risk factors for IgAN, while the II genotype was an advantageous factor for IgAN.

This study was not the first pooled analysis to explore the relationship between ACE I/D polymorphism and IgAN; a small amount of previous meta-analysis about this 


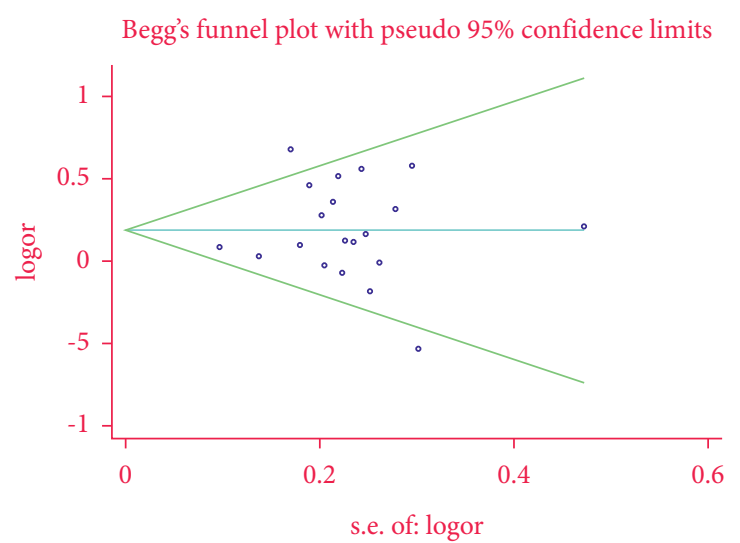

(a)

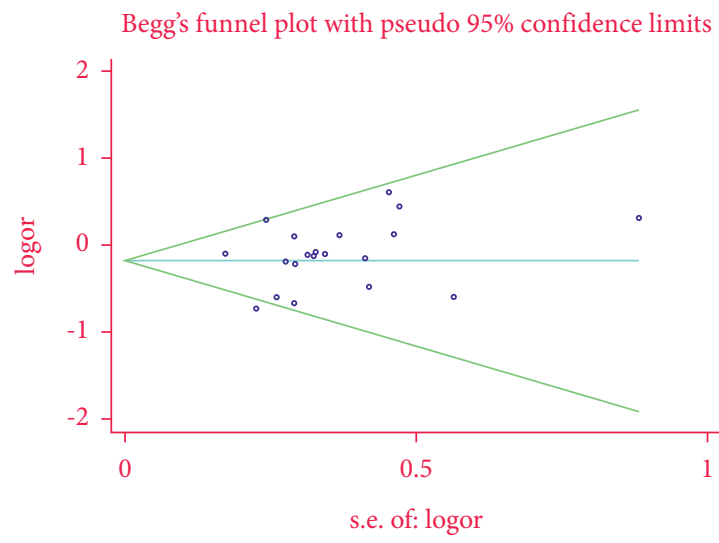

(c)

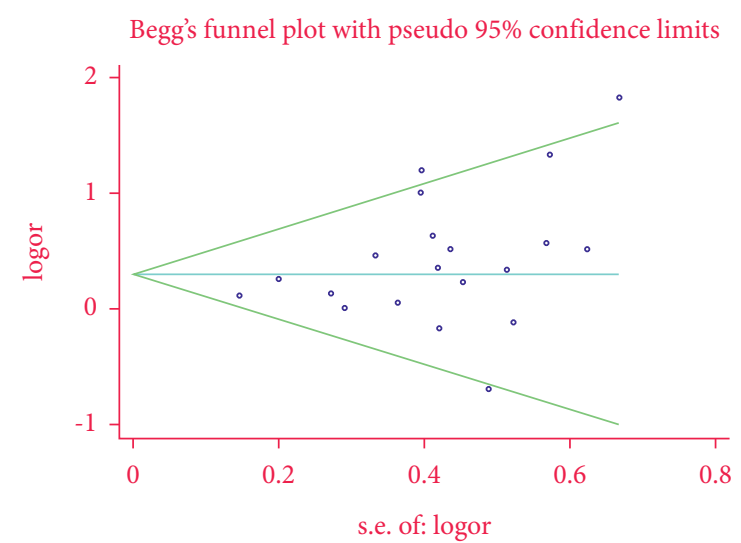

(b)

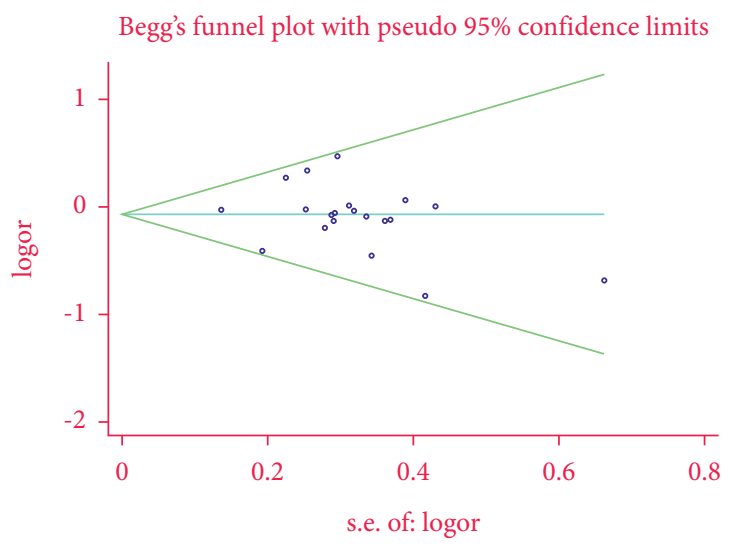

(d)

Figure 5: The funnel plots of different pooled analysis models. (a) Allele D vs. allele I; (b) genotype DD vs. genotype ID + II; (c) genotype II vs. genotype DD + ID; and (d) genotype ID vs. genotype DD + II.

controversial issue has been performed. In 2001 and 2006, two meta-analyses including only 5 reports have been completed [38,39]; these two research studies found that the association between the genetic susceptibility of IgAN and ACE I/D gene polymorphism was not significant. However, another pooled analysis performed by Yong showed that the ACE I/D polymorphism DD genotype was associated with IgAN progression both in Asian and Caucasians patients and the DD genotype was associated with IgAN risk in Asians [40]. As the number of included studies in these pooled analyses was small, in order to gain a more credible result, we reexamined the related trials and included 21 studies. We found that the allele $D$ and genotype DD were correlated with IgAN risk and progression only in Asian patients. Similarly, Qin et al. found that the allele $D$ and genotype DD were associated with IgAN susceptibility only in Asians, but there was no significant association between the allele $D$ or genotype DD and the progression of IgAN [10]. Due to the fact that we included much more trials in our analysis compared to the previous research, we believed that our findings were more credible.

IgAN is a common type of glomerulonephritis globally, and it is a major cause of chronic renal failure among East Asian countries. The pathogenesis of IgAN is extremely complex, and immunological renal injury mediated by $\operatorname{IgA}$ is traditionally associated with IgAN $[1,2]$. It has been demonstrated that IgA immune complexes depositing in the glomerular mesangium could activate inflammatory response, profibrotic cell proliferation, and even the formation of a glomerular crescent [3]. But, more and more research suggested that renin-angiotensin-aldosterone system (RAAS) activation played a vital role in the development and occurrence of IgAN. Angiotensin II (AT II) was a pivotal factor of RAAS, and growing evidence indicated that AT II was a potential proinflammatory mediator associated with the renal tubule interstitial fibrosis [41]. The activation of AT II resulted in the production of various inflammatory cytokines, such as TNF-a, IL-6, IL-8, and TGF- $\beta$ [42]. Consequently, these cytokines could greatly promote the occurrence and development of IgAN.

Recently, the researchers found that IgAN was also influenced by a confluence of environmental and genetic factors. Familial aggregation of IgAN indicated that genetic factor might participate in the pathogenesis of IgN [43]. With the technological development of genetic studies, especially the Genome Wide Association Study widely used, several SNPs within immune- or hypertension-related genes have been found significantly associated with IgAN. ACE was a pivotal factor of RAAS, the ACE gene contained 26 exons and 25 introns locating on 17q23 [6], and some polymorphic 
genetic markers of ACE gene have been found. Among these polymorphic markers, insertion or deletion $(\mathrm{I} / D)$ polymorphism (rs4340) of a $287 \mathrm{bp} \mathrm{Alu}$ in the 16th intron was the most investigated [6]. As mentioned earlier, there was a close relationship between the occurrence of IgAN and RAAS activation, and ACE played a vital role in the activation of angiotensin II. It was worth noting that the ACE level was strongly linked with ACE I/D polymorphism, and in those patients with the ACE DD genotype, the level of ACE expression and activity both in renal tissue and in serum were all markedly increased $[44,45]$. The insertion or deletion of base in the ACE gene might alter the expression or stabilization of ACE via influencing the stability of ACE mRNA. Thus, it could be seen that ACE $D$ allele carriers had higher ACE level and consequently possessed higher risk to IgAN vulnerability.

In this study, the pooled analysis results indicated that the relationship between $\mathrm{I} / D$ polymorphism of ACE gene locus and IgAN risk was inconsistent in different races.

In Asian and Chinese patients, we found that the genotype DD, II, and allele $D$ were associated with the vulnerability and progression of IgAN, but there was no evident correlation in Caucasian patients. This might be due to the differences in the environment and genetic backgrounds. Also, ACE inhibitors could affect the analysis results, while some studies in Chinese subjects did not clearly state whether to exclude those patients using ACE inhibitors. In short, the understanding about the ACE I/D genetic susceptibility difference was acquainted scarcely, and future research is needed to explore the specific mechanisms.

Some potential limitations should be discussed in our study. Firstly, the sample sizes in some included trials were small. Secondly, public bias was existed in this meta-analysis. Third, the included trials were from various countries, but the trials were published only in English and Chinese, which would result in reporting bias. Fourth, some included studies did not clearly state whether to exclude those subjects using ACE inhibitors. Finally, our study was mainly focused on ACE I/D genetic alteration, and the relationship between many other genes SNPs and IgAN susceptibility needed to be further explored.

\section{Conclusions}

Our pooled analysis supported that ACE gene locus I/D polymorphisms were linked with the susceptibility and progression of IgAN in Asian and Chinese individuals. ACE gene locus allele $D$ and genotype DD could be risk factors of IgAN vulnerability. Conversely, those subjects carrying the ACE II genotype would reduce the risk of IgAN susceptibility. However, no obviously correlation was found between ACE I/D gene polymorphism and IgAN in Caucasian patients. In future studies, much more high-quality trials are required to clarify it.

\section{Abbreviations}

SNPs: Single-nucleotide polymorphisms

HWE: Hardy-Weinberg equilibrium

OR: Odds ratio

CIs: Confidence intervals

\section{Data Availability}

The data used to support the findings of this study are available from the first author and corresponding author upon request. Since this is a pooled analysis, data from previous published studies were used.

\section{Conflicts of Interest}

The authors declare no conflicts of interest.

\section{Authors' Contributions}

Shi-kun Yang and Fen-fen Chu analyzed the data for the manuscript and wrote the manuscript. Shi-kun Yang, Fenfen Chu, and Wen-li Zeng performed the literature search. Wen-li Zeng and Shi-kun Yang edited the manuscript.

\section{Acknowledgments}

This study was supported by the Science and Technology Planning Project of Hengyang City (2019jh011012), the Hunan Provincial Health Commission Project (202103050178), and the Hunan Provincial Clinical Medical Technology Innovation Guide Project (2020SK53601).

\section{References}

[1] J. C. Rodrigues, M. Haas, and H. N. Reich, "IgA nephropathy," Clinical Journal of the American Society of Nephrology, vol. 12, no. 4, pp. 677-686, 2017.

[2] M. F. Soares and I. S. D. Roberts, "IgA nephropathy," Current Opinion in Nephrology and Hypertension, vol. 26, no. 3, pp. 165-171, 2017.

[3] S. C. Yeo, C. K. Cheung, and J. Barratt, "New insights into the pathogenesis of IgA nephropathy," Pediatric Nephrology, vol. 33, no. 5, pp. 763-777, 2018.

[4] M. Li and X. Yu, "Genetic study of immunoglobulin A nephropathy: from research to clinical application," Nephrology, vol. 23, no. 4, pp. 26-31, 2018.

[5] V. E. Tikhomirova, O. A. Kost, O. V. Kryukova et al., "ACE phenotyping in human heart," PLoS One, vol. 12, no. 8, Article ID e0181976, 2017.

[6] B. Rigat, C. Hubert, F. Alhenc-Gelas, F. Cambien, P. Corvol, and F. Soubrier, "An insertion/deletion polymorphism in the angiotensin I-converting enzyme gene accounting for half the variance of serum enzyme levels," Journal of Clinical Investigation, vol. 86, no. 4, pp. 1343-1346, 1990.

[7] D. Crisan and J. Carr, "Angiotensin I-converting enzyme," Journal of Molecular Diagnostics, vol. 2, no. 3, pp. 105-115, 2000.

[8] J. Teranishi, R. Yamamoto, Y. Nagasawa et al., "ACE insertion/deletion polymorphism (rs1799752) modifies the renoprotective effect of renin-angiotensin system blockade in patients with IgA nephropathy," Journal of the Renin-Angiotensin-Aldosterone System, vol. 16, no. 3, pp. 633-641, 2015.

[9] M. Pawlik, A. Mostowska, M. Lianeri, A. Oko, and P. P. Jagodziński, "Association of aldosterone synthase (CYP11B2) gene -344T/C polymorphism with the risk of primary chronic glomerulonephritis in the Polish population," Journal of the Renin-Angiotensin-Aldosterone System, vol. 15, no. 4, pp. 553-558, 2014. 
[10] Y.-H. Qin, T.-B. Zhou, L.-N. Su, F.-Y. Lei, W.-F. Huang, and Y.-J. Zhao, "Association between ACE polymorphism and risk of IgA nephropathy: a meta-analysis," Journal of the Renin-Angiotensin-Aldosterone System, vol. 12, no. 3, pp. 215-223, 2011.

[11] C. B. Begg and M. Mazumdar, "Operating characteristics of a rank correlation test for publication bias," Biometrics, vol. 50, no. 4, pp. 1088-1101, 1994.

[12] P. N. Harden, P. A. Rowe, R. S. C. Rodger et al., "Polymorphisms in angiotensin-converting-enzyme gene and progression of IgA nephropathy," The Lancet, vol. 345, no. 8964, pp. 1540-1542, 1995.

[13] H. D. Huang, F. J. Lin, X. J. Li, L. R. Wang, and G. R. Jiang, "Genetic polymorphisms of the renin-angiotensin-aldosterone system in Chinese patients with end-stage renal disease secondary to IgA nephropathy," Chinese Medical Journal, vol. 123 , no. 22 , pp. 3238-3242, 2010.

[14] T. E. Hunley, B. A. Julian, J. A. Phillips et al., "Angiotensin converting enzyme gene polymorphism: potential silencer motif and impact on progression in IgA nephropathy," Kidney International, vol. 49, no. 2, pp. 571-577, 1996.

[15] Y. K. Lau, K. T. Woo, H. L. Choong et al., "ACE gene polymorphism and disease progression of IgA nephropathy in Asians in Singapore," Nephron, vol. 91, no. 3, pp. 499-503, 2002.

[16] Y.-K. Lau, K.-T. Woo, H.-L. Choong et al., "Renin-angiotensin system gene polymorphisms: its impact on IgAN and its progression to end-stage renal failure among Chinese in Singapore," Nephron Physiology, vol. 97, no. 1, pp. p1-p8, 2004.

[17] L. Frimat, C. Philippe, M.-N. Maghakian et al., "Polymorphism of angiotensin converting enzyme, angiotensinogen, and angiotensin II type 1 receptor genes and end-stage renal failure in IgA nephropathy," Journal of the American Society of Nephrology, vol. 11, no. 11, pp. 2062-2067, 2000.

[18] K. Maruyama, M. Yoshida, H. Nishio et al., "Polymorphisms of renin-angiotensin system genes in childhood IgA nephropathy," Pediatric Nephrology, vol. 16, no. 4, pp. 350-355, 2001.

[19] Y. Pei, J. Scholey, K. Thai, M. Suzuki, and D. Cattran, “Association of angiotensinogen gene T235 variant with progression of immunoglobin A nephropathy in Caucasian patients," Journal of Clinical Investigation, vol. 100, no. 4, pp. 814-820, 1997.

[20] J. C. Rodríguez-Pérez, A. Macías-Reyes, A. Jiménez-Sosa et al., "A synergistic association of ACE I/D and eNOS G894T gene variants with the progression of immunoglobulin A nephropathy - a pilot study," American Journal of Nephrology, vol. 30, no. 3, pp. 303-309, 2009.

[21] N. M. Santos, B. H. Ault, A. G. Gharavi et al., "Angiotensinconverting enzyme genotype and outcome in pediatric IgA nephropathy," Pediatric Nephrology, vol. 17, no. 7, pp. 496-502, 2002.

[22] S. Schmidt, E. Stier, R. Hartung et al., "No association of converting enzyme insertion/deletion polymorphism with immunoglobulin A glomerulonephritis," American Journal of Kidney Diseases, vol. 26, no. 5, pp. 727-731, 1995.

[23] P. Stratta, C. Canavese, G. Ciccone et al., "Angiotensin I-converting enzyme genotype significantly affects progression of IgA glomerulonephritis in an Italian population," American Journal of Kidney Diseases, vol. 33, no. 6, pp. 1071-1079, 1999.

[24] S. Suzuki, Y. Suzuki, Y. Kobayashi et al., "Insertion/deletion polymorphism in ACE gene is not associated with renal progression in Japanese patients with IgA nephropathy," American Journal of Kidney Diseases, vol. 35, no. 5, pp. 896-903, 2000.

[25] J. Syrjänen, X.-H. Huang, J. Mustonen, T. Koivula, T. Lehtimäki, and A. Pasternack, "Angiotensin-converting enzyme insertion/deletion polymorphism and prognosis of IgA nephropathy," Nephron, vol. 86, no. 2, pp. 115-121, 2000.

[26] R. Tanaka, K. Iijima, R. Murakami, M. Koide, H. Nakamura, and N. Yoshikawa, "ACE gene polymorphism in childhood IgA nephropathy: association with clinicopathologic findings," American Journal of Kidney Diseases, vol. 31, no. 5, pp. 774-779, 1998.

[27] K.-T. Woo, Y.-K. Lau, L. H. Choong et al., "Polymorphism of renin-angiotensin system genes in IgA nephropathy," $\mathrm{Ne}$ phrology, vol. 9, no. 5, pp. 304-309, 2004.

[28] H. Yoshida, T. Mitarai, T. Kawamura et al., "Role of the deletion of polymorphism of the angiotensin converting enzyme gene in the progression and therapeutic responsiveness of IgA nephropathy," Journal of Clinical Investigation, vol. 96, no. 5, pp. 2162-2169, 1995.

[29] W. X. Hu, Z. H. Liu, and Z. Tang, "Angiotensin converting enzyme gene polymorphism and the progression of IgA nephropathy," Medical Journal of Chinese People's Liberation Army, vol. 22, no. 5, pp. 327-329, 1997, Article in Chinese.

[30] R. Li, N. Zhang, and L. Kang, "Relationship between renin angiotensin system gene polymorphism and IgA nephropathy," Clinical Focus, vol. 22, no. 10, pp. 685-688, 2007, Article in Chinese.

[31] Y. H. Liao, W. Li, and Y. Guo, "The relationship between ACE gene polymorphism and IgA nephropathy in GuangXi," Journal of Guangxi Medical University, vol. 20, no. 5, pp. 689-690, 2003, Article in Chinese.

[32] S. W. Liu, X. M. Chen, and R. Ding, "Association of ACE gene insertion/deletion polymorphism with IgA nephropathy," Chinese Journal of Laboratory Diagnosis, vol. 9, no. 5, pp. 751-753, 2005, Article in Chinese.

[33] Z. H. Liu, C. H. Chen, and W. X. Hu, "The relationship between ACE, Angiotensin II gene polymorphism and IgA nephropathy," Chinese Journal of Medical Genetics, vol. 14, no. 3, pp. 180-182, 1997, Article in Chinese.

[34] X. Song, D. Xu, and Z. F. Zhao, "Polymorphisms of angiotensin converting enzyme, angiotensinogen and endothelial nitric oxide synthase gene in IgA nephropathy in Xinjiang Uygur," Journal of Clinical Nephrology, vol. 17, no. 3, pp. 154-159, 2017, Article in Chinese.

[35] F. F. Xu, Y. Q. Lv, and R. R. Shao, "The relationship between ACE gene insertion/deletion polymorphism and IgA nephropathy," Chinese Journal of Integrated Traditional and Western Nephrology, vol. 2, no. 2, pp. 95-96, 2001, Article in Chinese.

[36] Y. W. You, F. F. Yang, and X. Lin, "Gene polymorphism of renin angiotensin system in IgA nephropathy patients with renal damage," Journal of Chinese General Practice, vol. 17, no. 7, pp. 2365-2368, 2013, Article in Chinese.

[37] X. Zheng, Y. K. Zhang, and X. Y. Li, "The relationship between ACE gene polymorphism and IgA nephropathy," Chinese Journal of Nephrology, vol. 15, no. 6, pp. 379-380, 1999, Article in Chinese.

[38] F. P. Schena, C. D’Altri, G. Cerullo, C. Manno, and L. Gesualdo, "ACE gene polymorphism and IgA nephropathy: an ethnically homogeneous study and a meta-analysis," Kidney International, vol. 60, no. 2, pp. 732-740, 2001.

[39] V. Wiwanitkit, "Angiotensin-converting enzyme gene polymorphism is correlated to the progression of disease in 
patients with IgA nephropathy: a metaanalysis," Renal Failure, vol. 28, no. 8, pp. 697-699, 2006.

[40] D. Yong, W. Q. Qing, L. Hua et al., "Association of angiotensin I-converting enzyme gene insertion/deletion polymorphism and IgA nephropathy: a meta-analysis," American Journal of Nephrology, vol. 26, no. 5, pp. 511-518, 2006.

[41] G. Wolf, "Renal injury due to renin-angiotensin-aldosterone system activation of the transforming growth factor- $\beta$ pathway," Kidney International, vol. 70, no. 11, pp. 1914-1919, 2006.

[42] R. Niimi, A. Nakamura, and Y. Yanagawa, "Suppression of endotoxin-induced renal tumor necrosis factor- $\alpha$ and interleukin- 6 mRNA by renin-angiotensin system inhibitors," The Japanese Journal of Pharmacology, vol. 88, no. 2, pp. 139-145, 2002.

[43] F. Scolari, A. Amoroso, S. Savoldi et al., "Familial clustering of IgA nephropathy: further evidence in an Italian population," American Journal of Kidney Diseases, vol. 33, no. 5, pp. 857-865, 1999.

[44] S. Mizuiri, H. Hemmi, H. Kumanomidou et al., "Angiotensinconverting enzyme (ACE) I/D genotype and renal ACE gene expression," Kidney International, vol. 60 , no. 3 , pp. 1124-1130, 2001.

[45] W. L. Zeng, S. K. Yang, N. Song, and F. F. Chu, “The impact of angiotensin converting enzyme insertion/deletion gene polymorphism on diabetic kidney disease: a debatable issue," Nefrologia, vol. S0211-6995, no. 21, pp. 00158-162, 2021. 